\title{
The Relationship between Defense Expenditures and Employment in NATO Member States: Bootstrap Panel Causality Test
}

\author{
NATO Üyesi Ülkelerde Savunma Harcamaları ve İstihdam İlişkisi: \\ Bootstrap Panel Nedensellik Testi
}

\author{
Şerife ÖZŞAHIN ${ }^{1} \oplus$, Gülbahar ÜÇLER² $\odot$
}

\begin{abstract}
In recent years, global tensions, geopolitical risks, political crises, regional conflicts, and wars have played an important role in the increase of defense expenditures of countries. The economic effects of increased defense spending have become one of the frequently discussed topics. The aim of this study is to examine the causal relationship between defense expenditures and employment rates in 18 NATO member countries. To this end, the relationship between defense expenditures and employment rates were analyzed using the Kónya (2006) Bootstrap Panel Causality Test in the post-Cold War period. According to the findings from the 1991-2018 period, a causality relationship was found in 5 of the 18 countries in the panel from defense expenditures to employment, and in 3 of the 18 countries from employment rates to defense expenditures. Thus, it seems impossible to make a general inference about the causality relationship between defense expenditures and employment in NATO member countries.
\end{abstract}

Keywords: Defense expenditures, Employment, NATO member countries

JEL Classification: H56, E24, C23

\section{öz}

Son yıllarda küresel ölçekte yaşanan gerginlikler, jeopolitik riskler, siyasal krizler, bölgesel çatışmalar ve savaşlar ülkelerin savunma harcamalarını artırmasında önemli rol oynamıştır. Savunma harcamalarındaki artış, savunma harcamalarının yol açtığı ekonomik etkileri sıklıkla tartışılan konulardan biri haline getirmiştir. Bu çalışmanın amacı, NATO üyesi 18 ülkede savunma harcamaları ile istihdam oranları arasındaki nedensellik ilişkisini incelemektir. Bu amaçla, Soğuk Savaş sonrası dönemde savunma harcamaları ve istihdam oranları arasındaki ilişki Kónya (2006) Bootstrap Panel Nedensellik Testi ile analiz edilmiştir. 19912018 döneminden elde edilen bulgulara göre panelde yer alan 18 ülkenin 5 'inde savunma harcamalarından istihdama doğru, 3 'ünde ise istihdam oranlarından savunma harcamalarına doğru
1Doç. Dr., Necmettin Erbakan Üniversitesi, Siyasal Bilgiler Fakültesi, İktisat Bölümü, Konya, Türkiye

${ }^{2}$ Doç. Dr., Kırşehir Ahi Evran Üniversitesi, İktisadi ve İdari Bilimler Fakültesi, İktisat Bölümü, Kırşehir, Türkiye

ORCID: S..Ö. 0000-0001-8310-1816; G.Ü. 0000-0002-5872-8577

Corresponding author/Sorumlu yazar: Şerife ÖZŞAHIN

Necmettin Erbakan University, Faculty of Political Sciences, Department of Economics, Konya, Turkey

E-mail/E-posta: sozsahin@erbakan.edu.tr

Submitted/Başvuru: 05.11.2020 Accepted/Kabul: 04.12.2020

Citation/Atıf: Ozsahin, S., \& Ucler, G. (2021). The relationship between defense expenditures and employment in nato member states: Bootstrap panel causality test. Istanbul Iktisat Dergisi - Istanbul Journal of Economics, 71(1), 231-249. https://doi.org/10.26650/ISTJECON2020-0022 
nedensellik ilişkisi tespit edilmiştir. Bu doğrultuda, NATO üyesi ülkelerde savunma harcamaları ile istihdam oranı arasındaki nedensellik ilişkisine dair genel bir çıkarımda bulunmak mümkün görünmemektedir.
Anahtar kelimeler: Savunma harcamaları, İstihdam, NATO üyesi ülkeler

JEL Sınıflaması: H56, E24, C23 


\section{Introduction}

In recent years, defense expenditures have constituted the most important expenditure item of the budget in many countries, and the significant dimension these expenditures have reached and its effects have become one of the most discussed topics. In many countries, especially after the end of the Cold War, governments advocated the reduction of defense expenditures to increase investments in other non-military fields such as education and health. However, unofficial wars between countries, recent increasing geopolitical risks in the world, technological developments in the arms and defense industry, and accordingly the increasing need for security have caused countries to use a significant part of their national budgets for defense expenditures. Declining defense expenditures with the end of the Cold War period started to increase again after the terrorist attack in the US in 2001. Although defense expenditures have decreased in Europe due to the global crisis in 2008, defense expenditures are increasing worldwide. According to the Stockholm International Peace Research Institute (SIPRI) 2018 Report, global security has deteriorated significantly over the past decade. The number of armed conflicts and the long-standing turmoil and conflicts in large parts of the Middle East and South Asia have increased international arms transfers and defense expenditures have begun to rise again on a global basis. According to the SIPRI reports, defense expenditures worldwide increased by $2.6 \%$ compared to the previous year and reached one point 822 trillion dollars, its highest level since the cold war. This figure is about $76 \%$ more than the post-war period in 1998. Defense expenditures in 2018 was equal to $2.1 \%$ of the global GDP, and the amount of military expenditures per capita was $\$ 239$. The top five countries with the highest defense expenditures in 2018 were the USA, China, Saudi Arabia, India, and France, respectively. The total defense expenditures of these countries constituted about $60 \%$ of global defense expenditures.

The 2008 global financial crisis caused the share of defense expenditures in GDP to decrease gradually in Europe. At this point, NATO's decision in 2014 to ensure equal burden sharing of the member countries regulates the share of defense expenditures of 29 member states in the GDP. During the Cold War, most of NATO's 
military expenditures were covered by the United States. However, in the postCold War period, uncertainty about equal responsibility and burden of the member states in the alliance caused problems (Bagbaslioglu, 2016). Defense expenditures of European allies in recent years are quite disproportionate compared to US defense expenditures. Defense expenditures of European allies in 1991 accounted for about $34 \%$ of NATO's total, while this rate has dropped to around $21 \%$ today. In 2018, NATO's total budget was 963 billion dollars and the US met about $67 \%$ of the budget of the organization with $\$ 649$ billion. Countries with a larger military expenditure share have a relatively higher defense burden. For this reason, the decision taken at the NATO summit in 2014 envisages that member countries will allocate $2 \%$ of their GDP to defense expenditures by 2024. Today, however, only four allied countries have achieved this goal except for the US. It is observed that the share of defense expenditures from the budget has decreased gradually in NATO ally countries especially after 1990. After 2008, the share of defense expenditures decreased further as European allies concentrated more on the banking sector, the Euro crisis, policies to close budget deficits and recovery. It is noteworthy that the share of defense expenditures of important countries of the alliance, especially Canada, Germany, Italy and Spain, is well below $2 \%$.

The study by Benoit (1978) which examined the relationship between defense expenditures and economic growth, and which also revealed a positive correlation between two variables led to a discussion on the link between defense expenditures and economic growth. However, there is no consensus on the direction of the impact of defense expenditures on growth due to the analysis methods, periodic, and national differences. On the other hand, although there is an extensive body of literature on the relationship between economic growth and defense expenditures, the number of studies examining the relationship between other determinants of economic growth and defense expenditures is very limited. Although the direction of impact is still controversial, the general belief in the literature is that defense expenditures have an impact on investments. While many economists argue that the increase in defense expenditures will have positive effects on employment, other economists argue that defense expenditures will negatively affect employment opportunities and employment, 
as it will reduce the amount of investment in other fields. In addition, the number of economists who state that there is no significant relationship between the two variables is not low. For example, according to Smith (1977), who examined the relationship between defense expenditures and employment using data from eight developed countries, stated there is a high correlation relationship between these two variables, while Chester's (1978) analysis of the same countries outside the USA showed that there is no significant relationship between defense expenditure and employment. The effects of defense expenditures on employment are concentrated on two main axes. The liberal view argues that defense expenditures will result in a crowding-out effect, waste and inefficiency in production, and consequently, the increased defense expenditures will negatively affect employment (Yildirim and Sezgin, 2003). While the conservative view argues that the increase in defense expenditures will indirectly or directly reduce unemployment. According to Baran and Sweezy (1966), military spending in monopoly capitalist economies alleviates unemployment and increases prosperity in these economies, especially in the USA. According to Baran and Sweezy (1966), defense expenditures increase production and investments by stimulating effective demand. The increase in investment will increase employment by creating additional employment opportunities.

The most important feature of defense expenditures is the use of advanced technology. Defense expenditures can increase private sector investments and thus labor demand through the positive impact of technological spillovers and infrastructure work. In addition, companies operating in the defense industry demand qualified workforce, which is expected to contribute positively to labor productivity. However, some defense industry branches requiring complex and advanced technology can partially operate with a labor-intensive production process (Simsek, 1989). The increase in the number of companies operating in the defense industry increases the sector's demand for skilled labor. In addition, the increase in the number of military and civilian personnel working in public defense services can contribute positively to employment by increasing production and investments to the total expenditures. According to the Keynesian view, when economy creates underemployment, the increase in defense 
expenditures will lead to positive demand shocks and will contribute positively to both economic growth and employment. On the other hand, the need for resources required to finance military expenditures will create an additional tax burden on workers and employers, which will negatively affect both labor supply and demand. The relocation activities in the defense industry will create frictional unemployment. In addition, the crowding-out effect created by defense expenditures will adversely affect private sector investments and thus employment. According to this classical view, the transfer of funds to unproductive areas while the economy is in full employment equilibrium will adversely affect growth and employment structure.

Given the positive and negative effects, the direction of the relationship between defense expenditures and employment is quite controversial in the literature; however, the common view is that defense expenditures affect employment rates. The aim of this study is to analyze the causal relationship between defense expenditures and employment for 18 NATO member states. Following the introduction section involving theoretical explanations on the subject, the literature review is given in the second section and the contribution of the study to the current literature is stated. In the third section, the dataset is introduced and in the fourth section, the method and empirical findings are explained. The study is completed with a conclusion.

\section{Literature Review and Contribution}

There is no consensus yet in the literature regarding the channels through which defense expenditures affect the labor market and in what direction. Dunne and Smith (1990) used the data for the 1962-1985 period and examined the causality relationship between defense expenditures and unemployment rates in 11 developed OECD countries. The findings revealed that only two of the 11 countries (Japan and England) have a unilateral causal relationship from defense expenditures to unemployment. Paul (1996) examined the causality relationship between defense expenditures and unemployment rates in 18 developed OECD countries using the data for the 1962-1988 period. The findings showed that 
there is no causal relationship between the two variables in 9 of the 18 countries included in the model. A unilateral causality was observed from defense expenditures to unemployment rates in four countries and from unemployment rates to defense expenditures again in 4 countries. Among all the countries, only Norway has a two-way causality. Barker, Dunne, and Smith (1991) investigated the economic effect of cuts in defense expenditures in the UK and found that these cuts significantly reduced unemployment and led to an increase in production. Wing (1991) used the data for the 1978-1980 period for Indonesia and came to the conclusion that defense expenditures create significant employment. The study conducted by Payne and Ross (1992) using the data for the 1960-1988 period revealed no relationship between defense expenditures and unemployment rates. Hooker and Knetter (1994) obtained results varying from state to state in their study on the relationship between defense expenditures and unemployment rates in US states. However, the study in which the data for the 1963-1992 period was analyzed argued that defense expenditures generally had negative effects on unemployment. Yildirim and Sezgin (2003) investigated the impact of defense expenditures on employment in Turkey for the 1950-1997 period. According to the study using the ARDL method, defense expenditures affect employment rates negatively both in the long and short term. The study by Dunne and Watson (2005) which investigated the relationship between defense expenditures and employment in nine OECD member countries found a significant relationship between the two during the Cold War period, while defense expenditures did not have any effect on employment rates in the postCold War period (1966-2002). Huang and Kao (2005) analyzed the effects of defense expenditures on employment in Taiwan with the ARDL method for the 1966-2002 period. They argued that defense expenditures positively affected employment in the long run but had a negative effect in the short run. Tang, Lai, and Lin (2009) used the data for the 1988-2004 period to examine the relationship between defense expenditures and unemployment rates in 46 developed and developing countries. Their findings suggested that defense expenditures increased unemployment rates in the middle- and low-income countries. Malizard (2014) used the data for the 1975-2008 period to examine the impact of defense expenditures on unemployment rates in France. The effect 
was analyzed using the ARDL method. According to the findings of the study, both military and non-military expenditures in the long and short term had a negative effect on unemployment. However, the effects of non-military expenditures on unemployment were weaker than that of the military expenditures. Navarro and Cabello (2015) examined the causality relationship between defense expenditures and unemployment rates in $15 \mathrm{EU}$ countries using data for the 1991-2012 period. They found a causal relationship in countries where the rate of personnel expenditures was high among defence expenditure. However, when the results were evaluated in general, the study emphasized that there were very few findings regarding the causality between defense expenditures and unemployment rates. Zhong, Chang, Tang, and Wolde-Rufael (2015) analyzed the relationship between defense expenditures and unemployment in G7 countries using the panel bootstrap causality method. They revealed a unilateral causality relationship from defense expenditures to unemployment in Canada, Japan and the United States, while they found a unilateral causality relationship from unemployment rates to defense expenditures in France and Germany. Qiong and Hu (2015) examined the effects of defense expenditures on economic growth and unemployment rates in China using the ARDL method for the 1991-2013 period. Their study showed that military expenditures positively affected unemployment, while non-military expenditures negatively affected unemployment rates both in the long and short run. Korkmaz (2015) used the 2005-2012 data to examine the effects of defense expenditures on economic growth and unemployment in Mediterranean countries. The findings suggested that defense expenditures negatively affected economic growth and increased unemployment. In their study for selected South Asian countries, Azam, Faisal, and Zaman (2015) analyzed the effects of defense expenditures on employment using data for the 1990-2013 period. The study which used the panel DOLS method revealed that defense expenditures reduced unemployment. Aydemir, Ozdemir, Kabadayı, and Emsen (2016) examined the relationship between unemployment and defense expenditures in $\mathrm{G} 20$ countries using data for the 1990-2014 period and reached the conslusion that defense expenditures decreased unemployment by disrupting the efficiency of resources in countries that are considered to be at full employment level. The authors 
suggested that the classical prediction worked in countries where unemployment rates in the economy were close to natural unemployment rates. Ucler (2017) investigated the effect of defense expenditures on unemployment rates in Turkey for the 1980-2014 period using the DOLS method and found that defense expenditures reduced unemployment. Topal (2018) investigated the relationship between military expenditures and unemployment in Turkey for the 1955-2016 period using the multiple structural breaks cointegration and time-varying causality tests. The findings of the study suggested that there was not a statistically significant relationship between defense expenditures and unemployment rates in Turkey. The causality analysis results showed that the causality relationship between the series is unstable, but periodic.

When existing literature on defense expenditures-employment relationship was analyzed, it showed that OECD countries, the US, and specific country examples were generally discussed. However, no studies have yet questioned the relationship between defense expenditures and employment in NATO member countries, which have been criticized by the US to increase the amount of defense expenditures and whose cooperation has frequently been questioned recently. This study expects to contribute to the literature by being the first study to examine the relationship between defense expenditures and employment in NATO member countries. In addition, when the studies in the literature were evaluated, it showed that tests ignored the cross-sectional dependence used in the analyses for the country groups. The causality relationship between the country group discussed in this study is investigated with the Kónya (2006) Bootstrap Panel Causality test, which takes cross-sectional dependence into account.

\section{Data}

In this study, the causality relationship between defense expenditures and employment rates in 18 NATO member countries ${ }^{1}$ were analyzed. Firstly, the presence of cross-sectional dependence among countries that constitute the panel was detected and the causality relationship was investigated with a method appropriate for the findings obtained. In the study, the period of 1991-2018 was 
analyzed considering the accessibility of the data of 18 NATO countries ${ }^{1}$. Functional relationships for the causality relationship between defense expenditures and employment rates are given in Equations 1 and 2.

$$
\begin{aligned}
& l E m p_{t}=f\left(l M E x p_{t}\right) \\
& l M E x p_{t}=f\left(l E m p_{t}\right)
\end{aligned}
$$

In Equations 1 and 2, IEmp represents employment rates, while IMExp denotes the share of defense expenditures in GDP. Employment rate data was compiled from the OECD Stat system, and the data on the share of defense expenditures in GDP was compiled from the SIPRI database. Natural logarithms of the data were taken for empirical analysis, which was performed using the Gauss 10 software.

\section{Methodology and Empirical Results}

In the panel data analysis, the presence of a cross-sectional dependence and the homogeneity of slope coefficients should be tested first among the units in the panel. Considering the result of these tests, the selection of a causality method suitable for the structure of the panel is of great importance for the reliability of the findings.

\subsection{Testing Cross-sectional Dependence and Slope Homogeneity}

The methods used to test the cross-sectional dependence differs according to the time period and the size of the cross-section. In panels where the time dimension is larger than the cross-section, Breusch and Pagan (1980) LM Pesaran (2004) $C D_{L M}$ and Pesaran, Ullah, and Yamagata (2008) $L M_{\text {adj. }}$ tests are used. While these methods indicate that there is no dependence between cross-sectional units in the null hypothesis, it is argued in the alternative hypothesis that there is a

\footnotetext{
1 Although there are 28 NATO member countries as of 2019, the data for some countries is rather limited as they have recently become a member of the union. For this reason, 18 NATO member countries were included in the study. These countries are Germany, Belgium, the UK, the USA, the Czech Republic, Denmark, France, Netherlands, Italy, Spain, Canada, Luxembourg, Norway, Hungary, Poland, Portugal, Turkey, and Greece.
} 
cross-sectional dependence. Breusch and Pagan (1980) LM test has asymptotic chi-square distribution, whereas Pesaran (2004) $C D_{L M}$ method shows normal distribution. The other method with standard normal distribution, Pesaran et al. (2008) $L M_{\text {adj., }}$ can be used in cases where $T \rightarrow \infty$ and $N \rightarrow \infty$.

$L M, C D_{L M}$ and $L M_{\text {adj. }}$ test statistics are defined in Equations 2, 3 and 4, respectively.

$$
\begin{gathered}
L M=T \sum_{i=1}^{N-1} \sum_{j=i+1}^{N} \hat{\rho}_{i j}^{2} \\
C D_{L M}=\sqrt{\frac{1}{N(N-1)} \sum_{i=1}^{N-1} \sum_{j=i+1}^{N}\left(T \hat{\rho}_{i j}^{2}-1\right)} \\
L M_{a d j}=\sqrt{\frac{2}{N(N-1)}} \sum_{i=1}^{\prime /} \sum_{j=i+1}^{N} \frac{(T-k) \hat{\rho}_{i j}^{2}-\mu_{T i j}}{\vartheta_{T i j}}
\end{gathered}
$$

Another issue to be taken into consideration in a panel data analysis is whether the slope coefficients of the parameters in the long-term equation have a homogeneous structure. When the slope coefficients are not homogeneous, it means that the countries that constitute the panel are heterogeneous. In this context, it is tested that the slope coefficients are homogeneous in the null hypothesis and heterogeneous in the alternative hypothesis. Slope homogeneity, controlled through a statistical program developed by Pesaran and Yamagata (2008), is a standardized version of the Swamy (1970) test. The $\tilde{\Delta}$ statistics, which tests the homogeneity of the slope coefficients under the condition of $(N, T \rightarrow \infty)$, has a standard normal distribution. Pesaran and Yamagata (2008) also developed the adjusted version of the $\tilde{\Delta}$ statistics $\left(\tilde{\Delta}_{\text {adj.j }}\right)$ so that it could give consistent results in small samples. $\tilde{\Delta}$ and $\left(\tilde{\Delta}_{\text {adj. }}\right)$ statistics are given in Equations 6 and 7. 


$$
\begin{gathered}
\tilde{\Delta}=\sqrt{N}\left(\frac{N^{-1} \tilde{S}-k}{\sqrt{2 k}}\right) \\
\tilde{\Delta}_{a d j .}=\sqrt{N}\left(\frac{N^{-1} \tilde{S}-E\left(\tilde{Z}_{i T}\right.}{\sqrt{\operatorname{var} \tilde{Z}_{i T}}}\right)
\end{gathered}
$$

Cross-sectional dependence and slope homogeneity test results of the panel examined in this study are reported in Table 1 . The results of $L M, C D_{L M}$ and $L M_{a d j}$ cross-sectional dependence tests demonstrate that the null hypothesis of no cross-sectional dependence is rejected at $99 \%$ significance level, meaning that a shock that will emerge in one of the 18 NATO countries in the panel affects another.

Table 1: Cross-Sectional Dependency and Slope Homogeneity Test Results

\begin{tabular}{|l|c|c|c|c|c|}
\hline \multirow{2}{*}{} & \multicolumn{4}{|c|}{ Cross-Sectional Dependence } & \multicolumn{2}{c|}{ Slope Homogeneity } \\
\cline { 2 - 6 } & $\mathrm{LM}$ & $\mathrm{CD}_{\mathrm{LM}}$ & $\mathrm{LM}_{\text {adj. }}$ & $\tilde{\Delta}$ & $\tilde{\Delta}_{\text {adj. }}$ \\
\hline IMExp & $497.874^{\star \star \star}$ & $19.715^{\star \star \star}$ & $11.149^{\star \star \star}$ & $43.714^{\star \star \star}$ & $47.081^{\star \star \star}$ \\
\hline IEmp & $355.921^{\star \star \star}$ & $11.600^{\star \star \star}$ & $12.222^{\star \star \star}$ & & \\
\hline
\end{tabular}

Note: ${ }^{* *}$ denotes the rejection of null hypothesis in statistical significance at $1 \%$.

Another test result reported in Table 1 relates to the homogeneity of the slope coefficients. The findings show that the null hypothesis, which states that the slope coefficients are homogeneous, has been rejected at $99 \%$ significance level and the countries have their own specific features. In line with these findings, the Kónya (2006) bootstrap causality test, which takes the cross-sectional dependence and slope heterogeneity features into account, is applied in order to investigate the causality relationship between defense expenditures and employment.

\subsection{Panel Causality Test}

The Panel VECM (Vector Error Correction Model) and Canning and Pedroni (2008) tests developed to detect the presence of causality relationship in panel data analysis do not take cross-sectional dependence into consideration. Also, 
these tests can be used when the variables are co-integrated. The methods of Dimitrescu and Hurlin (2012) and Emirmahmutoglu and Kose (2011), which do not require a cointegration relationship, do not take into account cross-sectional dependence, although they consider the heterogeneous structure of the panel. Kónya (2006) bootstrap causality test is the most suitable method that can be used in cross-sectional dependence and heterogeneity conditions. Furthermore, this method, which uses country-specific bootstrap critical values, has an advantage over other causality methods since it does not require unit root and cointegration tests (Kónya, 2006, p. 981).

In the light of the findings in Table 1, the country-specific heterogeneity and cross-sectional dependence characteristics of the panel consisting of 18 NATO countries were determined. Accordingly, in order to investigate the causality relationship, Kónya (2006) bootstrap causality test was applied as a method suitable for the structure of the panel. This method is based on the Seemingly Unrelated Regressions (SUR) estimator developed by Zellner (1962). This method, which takes country-specific heterogeneity into account, uses bootstrap critical values for each cross-section in the panel. For this reason, the $x_{t}$ and $y_{t}$ variables do not need to be stationary (Kónya, 2006, p. 981).

This method is based on the systems of equations in Equations 8 and 9.

$$
\begin{array}{r}
y_{1, t}=\alpha_{1,1}+\sum_{l=1}^{m l y_{1}} \beta_{1,1, l} y_{1, t-1}+\sum_{l=1}^{m l x_{1}} \gamma_{1,1, l} x_{1, t-1}+\varepsilon_{1,1, t} \\
y_{2, t}=\alpha_{1,2}+\sum_{l=1}^{m l y_{1}} \beta_{1,1, l} y_{1, t-1}+\sum_{l=1}^{m l x_{1}} \gamma_{1,1, l} x_{1, t-1}+\varepsilon_{1,1, t} \\
y_{N, t}=\alpha_{1, N}+\sum_{l=1}^{m l y_{1}} \beta_{1, N, l} y_{N, t-1}+\sum_{l=1}^{m l x_{1}} \gamma_{1, N, l} x_{N, t-1}+\varepsilon_{1, N, t}
\end{array}
$$

and

$$
\begin{array}{r}
x_{1, t}=\alpha_{2,1}+\sum_{l=1}^{m l y_{2}} \beta_{2,1, l} y_{1, t-1}+\sum_{l=1}^{m l x_{2}} \gamma_{2,1, l} x_{1, t-1}+\varepsilon_{2,1, t} \\
x_{2, t}=\alpha_{2,2}+\sum_{l=1}^{m l y_{2}} \beta_{2,1, l} y_{1, t-1}+\sum_{l=1}^{m l x_{2}} \gamma_{2,1, l} x_{1, t-1}+\varepsilon_{2,1, t} \\
x_{N, t}=\alpha_{2, N}+\sum_{l=1}^{m l y} \beta_{2, N, l} y_{N, t-1}+\sum_{l=1}^{m l x_{2}} \gamma_{2, N, l} x_{N, t-1}+\varepsilon_{2, N, t}
\end{array}
$$


In Equations 8 and 9, $N$ represents the number of countries, $t$ denotes time period, I represents lag lenght, and $\varepsilon$ represents the error term. If all $y_{1, i}$ in Equation 8 are different from zero, but all $\beta_{2, i}$ in Equation 9 are equal to zero, it means that there is one-way causality from $X$ to $Y$. When all $y_{1, i}$ are equal to zero, but all $\beta_{2, i}$ are different from zero, it means that there is a one-way causality relationship from $\mathrm{Y}$ to $\mathrm{X}$. When $y_{1, i}$ and $\beta_{2, i}$ are different from zero, it means there is a two-way causality relationship between $Y$ and $X$, whereas when $y_{1, i}$ and $\beta_{2, i}$ are equal to zero, it means there is no causality relationship (Kónya, 2006, p. 981).

In the first stage of the Kónya (2006) Bootstrap panel causality test applied through a five-step procedure, Equality 8 is estimated, and error terms are reached under the null hypothesis that there is no causality from $X$ to $Y$. The error terms are re-sampled in the second stage. In the third stage, based on the formula given in Equation 10, the bootstrap sample is created with the assumption that $X$ is not the cause of $Y$.

$$
y_{i, t}^{*}=\hat{\alpha}_{1, i}+\sum_{l=1}^{m l y_{1}} \hat{\beta}_{1, i, l} y_{i, t-1}^{*}+\varepsilon_{H o, i, t}^{*}
$$

In the fourth stage, $y_{1, i}$ is replaced by $y_{1, i}^{*}$ in Equation 8 without any parameter constraints and the Wald test is applied to test the null hypothesis indicating that there is no causality for each country. In the fifth and last stage, the distribution of Wald test statistics is improved by repeating steps 2, 3 and 4 many times. Then, the appropriate percentile is selected in the sample distribution and bootstrap critical values are determined (Kónya, 2006, p. 985-986).

According to this method, when the Wald statistics calculated for each country is greater than the bootstrap critical values at the level of significance, the null hypothesis stating that there is no causality is rejected. In other words, when the Wald statistics is greater than the bootstrap critical value, it means that there is causality from the independent variable to the dependent variable.

The results of the Kónya (2006) Bootstrap panel causality test in the 18 NATO countries are reported in Table 2. 
Table 2: Kónya (2006) Bootstrap Panel Causality Test Results

\begin{tabular}{|c|c|c|c|c|c|c|c|c|}
\hline \multicolumn{5}{|c|}{ Ho: IMExp does not Granger cause IEmp } & \multicolumn{4}{|c|}{ Ho: IEmp does not Granger cause IMExp } \\
\hline \multirow[t]{2}{*}{ Country } & \multirow{2}{*}{$\begin{array}{c}\text { Wald } \\
\text { Statistics }\end{array}$} & \multicolumn{3}{|c|}{$\begin{array}{c}\text { Bootstrap } \\
\text { Critical Values }\end{array}$} & \multirow{2}{*}{$\begin{array}{c}\text { Wald } \\
\text { Statistics }\end{array}$} & \multicolumn{3}{|c|}{$\begin{array}{c}\text { Bootstrap } \\
\text { Critical Values }\end{array}$} \\
\hline & & $1 \%$ & $5 \%$ & $10 \%$ & & $1 \%$ & $5 \%$ & $10 \%$ \\
\hline Belgium & 2.512 & 16.411 & 16.411 & 13.736 & 5.244 & 33.994 & 33.994 & 7.914 \\
\hline Canada & 1.853 & 38.238 & 38.238 & 9.784 & 0.563 & 45.789 & 45.789 & 12.77 \\
\hline $\begin{array}{l}\text { Czech } \\
\text { Republic }\end{array}$ & 12.005 & 36.869 & 36.869 & 12.187 & 0.380 & 30.570 & 30.570 & 21.968 \\
\hline Denmark & $6.218^{*}$ & 10.944 & 10.944 & 4.270 & 3.011 & 31.966 & 31.966 & 9.648 \\
\hline France & $14.142^{*}$ & 18.325 & 18.325 & 11.874 & 0.102 & 70.69 & 70.69 & 7.515 \\
\hline Germany & $56.548 * * *$ & 31.702 & 31.702 & 12.845 & 0.100 & 42.268 & 42.268 & 35.822 \\
\hline Greece & 0.1546 & 12.211 & 12.211 & 11.180 & 3.074 & 18.029 & 18.029 & 14.795 \\
\hline Hungary & 0.936 & 39.474 & 39.474 & 16.270 & 0.685 & 18.259 & 18.259 & 8.996 \\
\hline Italy & 3.794 & 67.060 & 67.060 & 9.011 & $13.826 *$ & 34.519 & 34.519 & 12.720 \\
\hline Luxemburg & $10.710 * * *$ & 3.926 & 3.926 & 0.937 & $11.247^{*}$ & 35.470 & 35.470 & 8.531 \\
\hline Netherland & 3.939 & 19.022 & 19.022 & 8.066 & 3.119 & 32.817 & 32.817 & 27.208 \\
\hline Norway & 0.344 & 40.606 & 40.606 & 9.883 & 4.741 & 10.333 & 10.333 & 6.748 \\
\hline Poland & $5.535^{\star \star *}$ & 5.085 & 5.085 & 4.675 & $20.902^{*}$ & 31.220 & 31.220 & 14.45 \\
\hline Portugal & 1.276 & 45.222 & 45.222 & 14.234 & 4.519 & 27.504 & 27.504 & 11.808 \\
\hline Spain & 0.9102 & 25.755 & 25.755 & 6.817 & 1.846 & 21.615 & 21.615 & 15.60 \\
\hline Turkey & 0.6092 & 6.423 & 6.423 & 5.985 & 2.021 & 62.70 & 62.705 & 44.66 \\
\hline UK & 1.290 & 7.241 & 7.241 & 6.329 & 5.703 & 42.596 & 42.596 & 29.472 \\
\hline USA & 1.011 & 14.608 & 14.608 & 13.950 & 0.840 & 53.379 & 53.379 & 25.238 \\
\hline
\end{tabular}

Note: ${ }^{* * *}$ and * indicate significance at the 0.01 and 0.10 levels, respectively. Bootstrap critical values are obtained from 10,000 replications.

According to the findings presented in Table 2, the null hypothesis of nocausality from the defence expenditure to employment is rejected in 5 of the 18 NATO countries in the panel. When the causality relationship is analyzed from employment rates to defense expenditures, causality relationship was found in three countries. There is a causality relationship from defense expenditures to employment in Germany, Luxembourg, and Poland at $99 \%$ significance level and in Denmark and France at $90 \%$ significance level. The causality findings from employment rates to defense expenditures indicate that there is causality in Italy, 
Luxembourg, and Poland at $90 \%$ significance level. When the findings for the 1991-2018 period were evaluated collectively, a bidirectional causality relationship was found between defense expenditures and employment rates in two countries (Luxembourg and Poland), while no causality relationship was found between the two variables in 12 countries (Belgium, the UK, the USA, the Czech Republic, Netherlands, Spain, Canada, Norway, Hungary, Portugal, Turkey, and Greece).

\section{Conclusion}

No consensus has yet been reached on the direction of the relationship between defense expenditures and employment and the causality relationship in the economics literature. However, it would not be wrong to say that there is a consensus in the literature that the relationship between these two variables may differ from period to period and from country to country. According to the classical view, due to defense expenditures, resources are shifted from productive areas to non-productive areas and thus growth is affected negatively. In this case, according to the classical view, in an economy with full employment, defense expenditures direct the workforce from productive areas to non-productive areas, and consequently, the volume of employment does not change. On the other hand, according to the Keynesian view, an increase in defense expenditures moves the economy from underemployment to full employment by increasing aggregate demand.

In this study, the relationship between defense expenditures and employment rates in 18 NATO member countries was analyzed using the Kónya (2006) Bootstrap Panel Causality Test for the 1991-2018 period. The findings revealed that among the 18 NATO member countries, there is a causality relationship from defense expenditures to employment in Germany, Luxembourg, Poland, Denmark and France, while there is a causality relationship from employment rates to defense expenditures in Italy, Luxembourg and Poland. Another finding of the study is that in two of the countries included in the model (Luxembourg and Poland), there is bilateral causality between defense expenditures and 
employment. The findings support the Keynesian view in only five of the 18 NATO member countries. While an increase in defense expenditures in these countries increases the level of employment through channels such as technological expansion, revival in effective demand, and the completion of private sector investments, the increase in the level of employment leads to economic growth and thus an increase in the budget allocated for defense expenditures. The fact that there is no relationship between defense expenditures and employment in the 12 countries in the panel does not allow an offer of any policy suggestions concerning the relationship between the two variables for 18 NATO member countries.

\footnotetext{
Peer-review: Externally peer-reviewed.

Conflict of Interest: The authors have no conflict of interest to declare.

Grant Support: The authors declared that this study has received no financial support.

Hakem Değerlendirmesi: D1ş bağımsız.

Çıkar Çatışması: Yazarlar çıkar çatışması bildirmemiştir.

Finansal Destek: Yazarlar bu çalışma için finansal destek almadığını beyan etmiştir.
}

\section{References/Kaynakça}

Aydemir, A.F., Ozdemir, D., Kabadayı, B., \& Emsen, Ö.S. (2016). The relationship between military expenditures and unemployment in G-20 states. 7th International Conference of Eurasian Economies (pp. 437-444). Kaposvár, Hungary.

Azam, M., Faisal K., \& Zaman, K. (2015). Military expenditure and unemployment nexus for selected south asian countries. Social Indicators Research, 127, 1103-1117.

Bagbaslioglu, A. (2016). A new solution seeking for a timeless issue burden sharing: Smart defence and NATO. Journal of Gazi Academic View, 10(19), 209-215.

Baran, P.A., \& Sweezy, P.M. (1966). Monopoly capital: An essay on the American economic and social order. New York: Monthly Reviews Press.

Barker, T., Dunne, P., \& Smith, R. (1991). Measuring the peace dividend in the United Kingdom. Journal of Peace Research, 28(4), 345-358.

Benoit, E. (1978). Growth and defense in developing countries. Economic Development and Cultural Change, 26(2), 271-280.

Breusch, T., \& Pagan, A. (1980). The lagrange multiplier test and its application to model specifications in econometrics. Reviews of Economics Studies, 47, 239-253.

Canning, D., \& Pedroni, P. (2008). Infrastructure, long-run economic growth and causality tests for cointegrated panels. The Manchester School, 76(5), 504-527.

Chester, E. (1978). Military spending and capitalist stability. Cambridge Journal of Economics, 3, 293-298. 
Dimitrescu, E., \& Hurlin, C. (2012). Testing for granger non-causality in heterogeneous panels. Economic Modelling, 29, 1450-1460.

Dunne, J.P., \& Watson, D. (2005). Manufacturing growth, technological progress and military expenditures. Working Paper No:0511. Retrieved from http://carecon.org.uk/DPs/0511.pdf

Dunne, P., \& Smith, R. (1990). Military expenditure and unemployment in the OECD. Defence and Peace Economics, 1(1), 57-73.

Emirmahmutoglu, F., \& Kose, N. (2011). Testing for granger causality in heterogeneous mixed panels. Economic Modelling, 28, 870-876.

Huang, J.T., \& Kao, A.P. (2005). Does defence spending matter to employment in Taiwan? Defence and Peace Economics, 16(2), 101-115.

Hooker, M., \& Knetter, M. (1994). Unemployment effect of military spending: Evidence from a panel of states. National Bureau of Economic Research Working Paper No:4889.

Kónya, L. (2006). Exports and growth: Granger causality analysis on OECD countries with a panel data approach. Economic Modelling, 23, 978-992.

Korkmaz, S. (2015). The effect of military spending on economic growth and unemployment in mediterranean countries. International Journal of Economics and Financial Issues, 5(1), 273-280.

Malizard, J. (2014). Military spending and unemployment in France. Defence and Peace Economics, 25(6), 635-642.

Navarro, M. S., \& Cabello, M. V. (2015). The causal relationship between military spending and unemployment in the EU 15. Social Science Research Network, Retrieved from SRN: https://ssrn. com/abstract=2550136 or http://dx.doi.org/10.2139/ssrn.2550136

Paul, S. (1996). Defence spending and unemployment rates: An empirical analysis for the OECD. Journal of Economic Studies, 23(2), 44-54.

Payne,J.E., \& Ross, K.L. (1992). Defense spending and the macroeconomy. Defence Economics, 3(2), 161-168.

Pesaran, M.H., \& Yamagata, T. (2008). Testing slope homogeneity in large panels. Journal of Econometrics, 142(1), 50-93.

Pesaran, M.H., Ullah, A., \& Yamagata, T. (2008). A bias-adjusted LM test of error cross-section independence. Econometrics Journal, 11, 105-127.

Pesaran, M.H. (2004). General diagnostic tests for cross-section dependence in panels. CESifo Working Paper No:1229; IZA Discussion Paper 1240.

Qiong, L., \& Hu J. (2015). Military expenditure and unemployment in China. Procedia Economics and Finance, 30, 498-504.

Smith, R.P. (1977). Military expenditure and capitalism. Cambridge Journal of Economics, 1(1), 61-76.

Simsek, M. (1989). Defense Industry in the Third World countries and Turkey, Ankara, SAGEB.

Stockholm International Peace Research Institute. (2018). SIPRI yearbook 2018-Armaments, disarmament and international security. Retrieved from https://www.sipri.org/sites/default/ files/2018-11/yb_18_summary_en.pdf

Swamy, P.A.V.B. (1970). Efficient inference in a random coefficient regression model. Econometrica, 38(2), 311-323. http://dx.doi:10.2307/1913012. 
Tang, J. H., Lai, C. C., \& Lin, E. S. (2009). Military expenditure and unemployment rates: Granger causality tests using global panel data. Defence and Peace Economics, 20(4), 253-267.

Topal, M.H. (2018). An analysis of relationship between military expenditure and economic growth in Turkey (1960-2016). Journal of Finance, 174, 175-202.

Ucler, G. (2017). The effect of defence spending on unemployment in Turkey: An econometric analysis for the period of 1980-2014. Journal of Yasar University, 12(46), 161-170.

Wing, M.M. (1991). Defence spending and employment in Indonesia. Defence Economics, 3, 83-92.

Yildirim, J., \& Sezgin, S. (2003). Military expenditure and employment in Turkey. Defence and Peace Economics, 14, 129-139.

Zellner, A. (1962). An efficient method of estimating seemingly unrelated regressions and tests for agregation bias. Journal of the American Statistical Association, 57, 348-368.

Zhong, M., Chang, T., Tang, D.P., \& Wolde-Rufael, Y. (2015). The causal nexus between military spending and unemployment in the G7: A bootstrap panel causality test. Defence and Peace Economics, 26(6), 609-622. 
